\title{
A.Gergely András
}

\section{MÜTERMEKTŐL KÉP-ESSZÉKIG \\ Újabb kötetek S. Nagy Katalintól}

\section{DOI 10.35402/kek.2021.1.12}

A Mütermek-kötet egyik, vagy inkább vállalhatóan megnevezhető lényege, meghatározó vonása, hogy nem alkuszik. Elbeszél, rávezet, karonfogva elvisz valahová egy festékes-pacás-oldószerbüzös műterembe, ahol addig járkál, addig kérdez, figyel, elemez, amíg meg nem jelenik a művészettörténész és esztéta számára legfontosabb tünemény, mégpedig a kép és művész kapcsolatának intimitása, titka, kérdés-válasz játéka, s emögött már szinte tapinthatóvá tehető az anyag, a kompozíció, a faktúra súgása, az idők változó témái és az alkotói habitus örökké kitettsége, változandósága. De mindezek előtt és helyett: az Alkotókat mütermükben faggató művészetkutató vallomása arról, amiről szólnia hivatott. Ám éppen ez az, amihez egyfelől a kompozicionális elemek társulnak és milyenségük magyarázata kap intim hátteret, no meg „a kép antropológiája” (hogy ily Belting-es legyek), a megjelenítés még rejtekező árnyalatai is beszédesek lesznek az értelmező olvasó (és emlékező!) szavai nyomán. Az emlékezés itt kulcsfogalom. Mert S. Nagy emlékezik, müvekre, helyzetekre, mütermekre, alkotói folyamatokra, tónusokra, ezekből ezrekre és tízezrekre: „...amikor a mütermekről írok, a saját emberi, művészeti élményeimről írok: amilyennek akkor láttam a festőt, szobrászt, ahogyan megmaradt emlékezetemben ő és a környezete. Legnehezebb felidézni a művek hatását, mert természetesen ezekről az évtizedek során változott a véleményem, ámbár nem annyira, mint ami indokolt is lehetne az idő távlatából. Mások máshogyan emlékeznek - nyilvánvaló. Ezek az írások nem műelemzések, nem a művészi pálya bemutatásai. Személyesek és mégis adalékul szolgálhatnak az érdeklődőknek...” (22-23. old.).

S az emlékezéshez vendégül, kíséröül hívott olvasó itt egyenesen abba az intimitásba csöppen, ahol a kreativitás dolgozik fóllásban. S. Nagy kutatóként már a hatvanas évek végétől járja a műtermeket, száz számra interjúzik az alkotókkal, évtizedekig dolgozza föl az összegyült anyagot, monográfiákat komponál a törmelékekből is, de sok-sok tíz- meg százórányi jelenléttel hitelesíti a tapasztalatot. Átéli, szinte belakja a mütermeket, beszélget, hallgat vagy szemlélődik, de tanúja a formálódás folyamatainak is sok tucat alkotó mühelyében. A látványban, az átalakulásban, az alapozástól a kiállításig folyamatban is részes. A festékkezelés mozdulatai, az alkotó tempója, álma vagy sejtése, haragja vagy óhaja, az anyag engedelmessé tétele, a frazírozás hangulati elemei, a belső harmóniák zenéje az, amit fölfedez magának. S. Nagy rajongó figyelme körébe tartozó kifejezési eszköz a zeneiség, melynek ismeretanyaga mintegy plasztikussá is válik a képekről beszélve és a mütermekben széttekintve. „Az 1969 januárjában Gedő Ilkánál látottak maradtak az alapélmények (az imprinting, a kötődés). Egyben annak az átélése, hogy a látvány közvetítette élmény erősebb, meghatározóbb számomra, mint a költészet és a zene..." /.../ „Kinyílt a világ, ráéreztem: ez az én közegem. Az ötven-hatvan éves (nekem akkor öreg), évtizedekig hallgatásra ítélt, akkoriban újra kiállítani kezdő művészeknek imponált a határozott érdeklődésem, odafigyelésem - az a képességem, hogy nagyon koncentráltan közelítettem a művekhez, érzékenyen érzékeltem a látottakat. Lassan, hosszan, elmélyülten néztem és láttam a lényegüket. Addig csak a versek (8-9 éves koromtól) és a klasszikus zene (12 éves koromtól) érintett meg bensőségesen, rejtélyesen meg persze a fák, vizek, dimbes-dombos tájak...” (7. old.).

S ez a személyes, mondhatnám történeti intimitással megközelített alkotói lét az, ami itt most soron van a nyolc esszében. „Lehetne az a cím: $A z$ életem helyszinei. Írtam már az Arnolfini Szalon esszéportálon városokról, tájakról, munkahelyekről, kiállításokról, képekről. Ebben a sorozatban a mütermek következnek. Remélem, meggyőzően és hitelesen tudom bemutatni a számomra fontos, szemléletemet, értékrendemet meghatározó művészek környezetét" - írja Egy fóállású müterem-látogató visszaemlékezései címü előhangban. ${ }^{1}$

De a bonyolult, nagy odafigyelést elváró kompozíció felöl szívesen kalandozik az egyes „képhangok” felé, a jelek és közlésmódok harmóniái, a „csuklógyakorlatok” és finom billentéstechnikák irányába.

1 h t t p://s zalon.arnolfini.h u / snk-egy-foallasu-muterem-latogato-visszaemlekezesei/ 
Rövid mondatokban, elbeszélő hangnemben, leíró (és ugyanakkor mégis vállalhatóan személyes) tónusban avat be, szinte Mester módjára vezeti kezünket az értelmezés felszínén, hogy utána mögé-világítson, $s$ rámutasson a fó hatás, a meghatározó elem, a hangsúlyok, kiemelések, cirkalmak és meggyőző állítások szintjének fontosságára, majd magyarázatára is. Sőt: mindezt a megismerendő művész és mű feltáró leírásával kiegészített megismerési folyamat-egész, a kutató technikái, a megértés esélyei felől hitelesíti, még inkább könnyítve a befogadói oldal pszichológiai hajlandóságának aktiválódását. Azt is megértjük ennélfogva, miért nemcsak a mű, hanem a mủhely, a keletkezés bölcsője, a világok születésének forrása vagy kelyhe az, aminek leírására vállalkozik, hanem amihez a habitus, a körülmények, a perszonális történelem, a kapcsolatok, a megértéstörténet szinte egész folyamata ott kell álljon a műtörténész előtt, amikor megnevezi alkotóját. „Sokat gondolkodtam azon, írjak-e elöljáróban a mủteremről mint munkahelyről. Nálunk nem túl szerencsés a műterem-helyzet - immár 120-130 éve. Már az 1880-as (!) években is panaszkodtak képzőművészeink, mennyire nincsenek munkára alkalmas műtermek a fơvárosban, és menynyire nincs pénzük, hogy építkezhessenek. Ellentétben a külföldön élő művészekkel. Ez a hagyomány máig folytatódott. Végül is nem bonyolódtam bele ebbe a nehéz kérdéskörbe. Remélem, a következő írásokból kiderül, kinek mi volt és milyen a müterme" (9. old.)

Ily módon a Mütermek. 8 esszé kötet $^{2}$ már indításával is szűkít, a sok évtizednyi tudástapasztalat csupán csekélyke töredékét jeleníti meg. Ebből is azt, ami a négy évtizeddel korábbi élményekből személyes-fontossá vált, és fóleg az 1969 és 1975 közötti műteremben töltött időket idézi meg: „Ezekhez kapcsolódtak az akkoriban általam rendezett kiállítások, valamint képzőművészeti írásaim és művészetszociológiai kutatásaim is. Nem győzöm hangsúlyozni, hogy visszaemlékezéseim nem tudományos igényüek, hanem nagyon is személyesek. Hiszen azt, akivé lettem, alapvetően meghatározták az Ország Lilinél, Illés Árpádnál, Anna Margitnál, Bálint Endrénél, Korniss Dezsőnél, Gedő Ilkánál, Vajda Júliánál és Schaár Erzsébetnél töltött órák, éveken át folytatott beszélgetések, mindaz, amit tőlük tanulhattam a képzőművészetről” (84. old.).

Az „akivé lettem” pedig nem kevés, s föleg nem eredménytelen, a pálya óriási és korszakos, mások

2 Paperbook 34. Arnolfini Archívum, 2016., 84 oldal által meg nem csinált munkákkal, öklömnyi vastag monográfiákkal több nyelven is kiadott kötetekkel „kikönyvezett”. Az ehhez vezető út pedig nem a talányos rejtélyek világa, hanem a kutató sajátja. Amikor, ahogyan s amiért a művek felé közelít, az alkotókat faggatja, az életműveket átfogni igyekszik, az maga is tele van az ismerkedés nyűgjeivel, derüjével, építő folyamatával. „Tanulatlan, műveletlen voltam, tehát ez a valami velem született adottság lehetett. Anyám nagyon szépen kézimunkázott, kötött, selyemgobelin képeket készített, nővérem egész életében fákat, erdőket rajzolt, talán volt a családban kötődés a képi nyelvhez. Szívesen és türelmesen magyaráztak azok, akiket a műtermükben 1968-tól újra és újra megkerestem, elsősorban az úgynevezett európai iskolások. Németh Lajos tanítványává fogadott, Körner Éva tanított, és Dávid Katalin is támogatta próbálkozásaimat. A képlátást, képláttatást Ország Lilitől, Anna Margittól, Bálint Endrétől, Korniss Dezsőtől, Vajda Júliától, Gedő Ilkától és Tóth Tibortól tanultam. A szobrászathoz nem igazán volt affinitásom, de két szobrászt nagyon kedveltem (azt hiszem, ők is engem), és sokat tanultam tőlük: Schaár Erzsébet és Pauer Gyula. Ennél jobb képzésben nem is részesülhettem volna" (7. old.)..., „mellettük álltam, és meglepett az az intenzitás, ahogy belevonzanak egy belőlük kisugárzó kapilláriarendszerbe (hogy ez hogyan történt meg, valójában erről szól a műterem-látogatásokról íródott, íródó esszésorozat)..." (60. old.).

Ez a személyesben a közös, müben a szuverén, megértésben és megnevezésben az intim, ugyanakkor valamiképpen mégis közössé tehető... - ez vezeti a megismerés útján is. Személyesség, kapcsolatok, ajánlások, egymásra érzések, bizalom, elkötelezett érdeklődés és közvetlenség-vágy, ami a művészeket is áthatja (legalább is többségüket, ha nem is mindenki engedi közelebb lépni, de $S$. Nagynak is megvan a maga érzékenysége, nem is akar mindenkihez egyformán kötődni vagy ugyanúgy megnyílni...), s végül ez az, ami a művészettörténész, a művészetszociológus, az intézményvezető és -alapító életút mellett az egyetemi tanításban bontakozik ki, közös publikációktól sem tartózkodva, hatások és benyomások sokaságát hagyva átadható örökségként. A kis kötet (roppant finom, érzékeny papírmunka, választékos tipográfiával és papírminőséggel!) több pontján feltűnik a sor: „Volt tanítványaimnak”, egykori miskolci, budapesti és nagykanizsai "hallgatóimnak", stb. Hagyaték ez, élő és változó örökség, melyre S. Nagy nemcsak kötetekben, előszavakban, 
de kiállításmegnyitókon, tárlatszervezésben, kurátorként évtizedek óta, sőt az Arnolfini Portálon a legszorgalmasabb képszolgáltatóként és szövegkomponálóként mindennaposan jelen van.

„Természetesen nem múltak el nyomtalanul a mütermekben töltött idők során szerzett tudások, az ott kialakult képérzékenység. Amikor hat évvel ezelőtt a tanszékvezetés, intézetigazgatás, tudományos pálya lezárult, fóként képelemző esszéket kezdtem írni (eddig három kötetben és online az Arnolfini Archívum gondozásában). És közben egyszer csak azt vettem észre, hogy előbb mütermekről készült fotókat, majd műtermekről festett képeket kezdek gyüjteni a számítógépemben. Előbb a fö kedvencekről: Klee, Rembrandt, az öreg Monet, Rothko, Bacon, Chagall, Giacometti, Miró, Ország Lili, Anna Margit, Vajda Lajos, majd egyre több mindenki, németalföldiektől a kortársakig (köztük afrikaiak és kínaiak is). Aztán körülbelül két éve egyszer csak rájöttem, hogy meg szeretném írni az emlékeimet, élményeimet a kezdetekről (1968-1975): Ország Lili, Anna Margit, Bálint Endre, Schaár Erzsébet és mások mütermeiről. És talán - de ez még nem biztos - a legutóbbi években tett kevés, ritka, de intenzív műhelylátogatásokról (Mózes Katalin, T. Horváth Éva, Kováts Borbála, Alföldi László, Gábos József, Zsubori Ervin)...”

S ami talán a személyes választás mellett, azzal együtt vagy abban is helyet kapva a kötet hangsúlyos része: ellépés, eltávolodás a mütörténet leíró-megjelenítő optikájától, s váltás egy nagylátószögü, de közelnézetre is alkalmas lencsére, mely nem pusztán fénykép készítésére, a pillanat rögzítésére alkalmas (persze arra is), de a közvetlenség személyes hitelével a mütermekbe „bekopogtatás” közvetlenségével, őszinteségével, naivitásával, s magával a megismerkedési folyamattal is hitelesíti a magánérdekűnek látszó közhasznút. Példaképpen az első portréban, Anna Margit különös világáról: „Milyen is volt az akkor 55 éves festő? Alacsony, kicsit testes, rövidre vágott haj, frufru, élénk-nyitott-szomorú tekintet, kihúzott szemöldök, erőteljes orr, irónia a szájszögletben, kis fülbevaló, erőteljes áll és kéz, zárt nyakú felsőrész. Határozott, barátságos, távolságtartó, hiú, rátarti, feszült, különös, nem mindennapi, eleven. Ország Lili szerint Anna Margit 'a neked való festő"”. Vagy a Látogatások festők özvegyeinél fejezetben: „De az igazi döbbenetet Czimra Gyula ember nélküli szobabelsői, konyhái keltették bennem. Nyugalom, derű, biztonság és varázslatosság áradt a csaknem üres terekből, az alig néhány tárgyból. Békés üresség, csend, ami mégis telítve van elmúlt és leendő hangokkal. Ilyen nincs is, gondoltam. A környezetünk nem ilyen, az emberek se, de mégis: a vágy a tisztaságra, az egyszerü létezésre, a mindennapi boldogság kereteire. Árkádiára, paradicsomi ártatlanságra - ami nincs. (De van, lehetséges: paraszt nagyapám kétosztatú, egyszerü házában a fehér búboskemence, a dikó, amelyen aludtam, s amelyet nappalra betoltak a nehéz dunyhákkal teli ágy alá; a domborított lovakkal díszített falióra ma a konyhámban -, és a lóistállóban a szalmával tömött ácsolt fafekhely. Czimrának való környezet.) Tudom, hogy sokan hidegnek vélik Czimra tereit, színeit, sokakat nem érint meg, zavart kelt bennük az üresség, az egyszerűség, a szinte semmire redukált látvány. Ami nálam van a vendégeket fogadó szobám falán, néhány festő barátomban is idegenkedést vált ki (nekik legszívesebben azt mondanám, gyere, fogd meg a kezem, lépjünk be együtt a képbe, ne szorongj, veled megyek, nem hagylak magadra). Gyerekkorom óta tágas terekbe, nagyvárosokba vágytam, messzeségekbe. Czimra képei láttán döbbentem rá, milyen tágas lehet a szűk tér is, milyen távlatok nyílhatnak az egymásba kapcsolódó terek által, milyen mélységek és messzeségek. Mi mindent mondhat el az emberről a közvetlen környezete, a tér, amelyet berendez magának. Akkor kezdtem felfedezni, hogy vannak festők, akik egész életükben önarcképeket festenek, bármi legyen is képeik tárgya, motívumaik..." (42. old.).

A képek kínálta belső világok és a mütermek belső világa közötti „résekben” szinte mindig ott van a személyes motiváltság egy sajátos vonása is, olykor csak mint kompozicionális elem: egy Ország Lili vagy Anna Margit vonal, színválasztás, jel, kifejező momentum mögött a rá- és belátó fontossága annak, hogy a modern magyar festészet legkiválóbbjai között mennyien képviseltetik magukat a zsidó kultúrából. Ez nem válogatás szempontja - de sokszor az egymásra találásé igen, vagy a közvetlen késztetések közötti nyomatékos elem. „Még meg kell említenem, hogy a kilencvenes évek végén megkeresett Bolmányi Ferenc (1904-1990) özvegye, és meghívott a Bartók Béla úti nagyméretű, tágas, világos müterembe, amelyben 1965 óta laktak férjével (a házat Lechner Ödön tervezte, és ez meghatározta miliőjét). Bolmányi Csontváry egykori mütermének közelében alakíthatta ki a sajátját. Az özvegy felkért, hogy írjak könyvet a férjéről. (Ez meg is történt: megjelent 2000-ben az 
Enciklopédia Kiadó gondozásában. Elsőnek az ragadott meg, hogy az ötvenes években, amikor még a jó festők, egykori posztimpresszionisták, modernek nagy része is beállt a sorba, és szocreál képeket festett, kiszolgálva a hatalmat, Bolmányi Ferenc öreg rabbikat festett, és zsinagóga belsőket rajzolt.) Ez azonban már másféle műterem-látogatás volt, mint 1969-ben a festőözvegyeknél - hiszen a második alkalomtól kezdve a munkára, a leendő könyvre koncentráltam. 55 éves voltam, nem pedig 25. Akkor és ott gondoltam át, milyen hamar és szerencsésen találtam meg 24-26 éves koromban azt a közeget, amellyel azonosulni tudtam (Anna Margit-, Ország Lili- és Chagall-könyv), és nem térítettek el az új műtermek, más szemléletmódok, másféle festők, emberek. Természetesen, másféle festők is közel kerültek hozzám (Czimra Gyula, Bene Géza), és másokról is írtam könyvet (Berczeller Rudolf Rezső, Bolmányi Ferenc, Deim Pál, Farkas István, Gábor Marianne, Paul Hargittai, Németh Géza, Péter Vladimir, T. Horváth Éva). Akik mellett következetesen kitartottam, azok a művészek, akikbe 24-25 évesen 'beleszerettem' - máig, és még a legutóbbi évtized, évek választásai is hozzájuk illeszkednek szemléletükben, formanyelvükben (például Mózes Katalin, Alföldi László, Kováts Borbála). Hűséges maradtam ifjúkorom ideáihoz, ideáljaihoz".

Az ifjúkor, s maga a fiatal művészettörténeti érdeklődése is szoros kapoccsá lesz nemegyszer, de más motívumok is. „Elöször 1969 januárjában voltam Gedő Ilka műtermében. Egy 1944 októberében, a gettóban készült önarckép rajzot tett az Emlékkönyvbe (én akkor születtem a nagykanizsai gyüjtőben, ahonnan 84 éves nagyanyámat, nagynénéimet, nagybátyámat, férjeiket, feleségüket és 28 unokatestvéremet szállították Auschwitzba, egyenesen a gázkamrába). Azt írta alá: 'Katalinnak első, felejthetetlen látogatása emlékére szeretettel, Gedő Ilka'. Férje pedig ezt: 'Katalinnak, szeretettel (és meglepődve vakmerő korszerűtlenségén, amely remélem korszakalkotó) Bíró Endre'. A korszerütlenségek közé tartozik a pszichológiai vonzatú interjúzás (Rorschach-teszttel): „Aztán az 1973-ban, a Miskolci Galériában rendezett Ámos Imre-Anna Margit-kiállításhoz válogattunk gondosan műveket. Közben hosszú életútinterjút és egy több száz választ tartalmazó Rorschach-tesztet is készítettem vele (Mérei Ferenc tanár úr segített a jelölésekben). Közel kerültünk egymáshoz. Amennyire csak lehetett. Amennyire ő engedte. Ennek bizonyítéka volt, hogy minden régi, háború előtt készült rajzát, akvarelljét és festményét előbányászta" - írja Anna Margit kapcsán. De a zsidóság és a továbbhurcolt pszichés súlyok jelenléte többek esetében visszatér (Gedő Ilka, Ország Lili, Vajda Lajos, Ámos Imre, Farkas István, Schaár Erzsébet, stb.), másokkal meg a paraszti környezet és értékeinek (ló, mázas tál, kancsók, dikó, búboskemence, stb.) tartós becse hozza közelbe a kutatói vonzalmakat, megint máskor „a nyugalom üres terei” - mint Czimra Gyula esetében, a „tanítói hajlandóság” - mint Illés Árpád, Korniss Dezső, Ország Lili esetében, vagy a súlyos örökséget méltón viselő jellem - mint Vajda Júlia, Kassák Lajosné és mások mühelyében.

Jó is lenne, kimásolni, s egyben átadni mindazt, amit $\mathrm{S}$. Nagy ebben a műterem-kötetben öszszefoglal. A létmódok, élethelyzetek, kicsiny festőmühelyek, szorongatott létformák, pénztelenség és sokszor-sokszor a méltó elfogadás, karrier és megélhetési könnyebbség legkisebb esélye nélküli vegetálás ül a kötet mélyén, melyhez olyan szerzői alázat, valódi megismerési éhség, érzékeny és emlékező hajlandóság, apró rítusoknak méltó becsét megadó finomság járul, melyre olykor még maga $S$. Nagy is rácsodálkozik. Amire nem, az a közös szegénység, a kivételes intellektuális nyitottság, az idejekoráneurópaiság, a meghatározó életeszme kiszolgáltatott követése, s maga az örökség, mely a festőműhelyek hagyományában szinte benne lakik, mint a tubusok, ecsetek, csöbrök, vásznak, anyagok, színek és rejtélyek gazdag köre. Jó lenne festőnként végigkövetni, amiket $S$. Nagy megjelenít - de ezek olykor egymásba kalandoznak, egyetlen közös korszakot vagy kört, hagyományt vagy habitust is hordoznak..., megtűzdelve a személyesség jeleivel mint érdeklődésváltás, szociológiai kutatási út és karrier, kiállításrendezések és könyvek sora, kísérletezések az összhangokkal, kontrasztokkal, modellekkel és mintázatokkal... Meg hát a mindenkori Emberrel, aki sokszor úgy is föszereplö, hogy nincs is jelen a színen.

A kötetet is hangulatilag zárja, az impressziók és műhelylátogatások sorát is berekeszti, ezért talán méltó zárásként még fölidézem, amit $S$. Nagy ír könyve 88. oldalán: „A Rottenbiller utcai zsúfolt, sötét lakásban mintha fénycsóvát tartott volna fölém Vajda Júlia, örökégőt, örökké világosítót. Mintha mi hárman együtt, Ô meg én (27 évesen), meg a jelenlévőnek érzett Vajda együtt beléptünk volna a képek kínálta utakra, ösvényekre, mint ama mesebeli kínai festő. Az a labirintus többé nem eresztett”. 
S ennek immár az is hagyománya, kelléke, tárgyi jegye tudott lenni, hogy $S$. Nagy Katalin megírta, $s$ most megosztotta velünk is. Immáron kötete is a műtermek része lehet. Hálák érte.

\section{Létképekről még csak eztán}

S. Nagy Katalin a fenti Mütermek-esszéket éppen öt esztendeje írta. $S$ ha mint művészeti író, művészettörténész, képértelmező és képgyűjtő alább hagyná minden tevékenységét, képeket akkor is válogatna, megnevezne, fölfedezne naponta. $S$ ezt teszi azóta is, mikor még az aktuális bevezetőjében ezt írta: „Írtam már az Arnolfini Szalon esszéportálon városokról, tájakról, munkahelyekről, kiállításokról, képekről. Ebben a sorozatban a mütermek következnek. Remélem, meggyőzően és hitelesen tudom bemutatni a számomra fontos, szemléletemet, értékrendemet meghatározó művészek környezetét". Nos igen, a remény bejött, de meg is maradt. Úgyannyira, hogy a tavaly megjelent Képekröl... 21 esszé kötet láthatóan a folytatás, a kiteljesítés, a keretbe tömörített mutatkozás része lehet. ${ }^{3}$

A mutatkozás persze többrétegü, a méltán személyestől a Rembrandt vagy Paul Klee „belülről látásáig”, s vissza a munkáig, a „kemény, hosszú, fegyelmezett küzdelem. Harc az idővel. Önmagammal” késztetéséig, vagy a társult örömig is. „Amikor esszét írok, menekülök az idő elől. Megállítom a múló időt. Megragadom az elszálló pillanatot. Csak a fehér papír van és a fekete toll, sorjáznak a sorok (mint vetéskor gyerekkoromban nagyapám lovai után), és egyszer csak már nincs is idő. Semmi nincs, csak a mondatokká formálódó szavak és a festményről készült színes nyomatok. Érzem a csendet. Az íróasztalom előtti, körüli tágas tér, a két ablakon és az erkélyajtón beáramló fény segít belépni a kiválasztott elemzendő mübe. Bal kezemnél persze a 15-20 oldal jegyzet, sűrűn teleírva apró betűimmel (olykor 2-3 hét, 2-3 hónap, 2-3 év olvasmányaiból és a fejemből a megőrizni vágyott gondolatok, idézetek, ötletek). Átélem, hogy vagyok, hogy létezem. /... / Az esszéírás: öröm. Volt egyszer már: 1987 és 1989 között. Aztán 2009 (tanszékvezetés, intézet, egyetemi és közéleti funkciók megszűnése) után nekikezdtem a képelemzö-esszéknek, a Micsoda útjaim...-nak és hasonlóknak. A közben eltelt két évtizedben rengeteget és kitartóan gondolkodtam

3 Létra Kiadó, Kaleidoscope Könyvek 4., Budapest, 2020., 171 oldal azon, hogyan lehet kialakítani azt a meghittséget a művel, ami ahhoz kell, hogy kendőzetlenül feltáruljon előttem a befejezett alkotás és az alkotási folyamat legkisebb mozzanata is, $s$ megláthassam, hogy a teremtő gondolat megnyilvánulásai, az ecsetvonások múlékony pillanatai miként válnak véglegessé. Az örökkévalóság részévé. Akartam hinni, hogy megtanulom a párbeszéd lehetőségét" - írja a bevezeto „magyarázkodásban”, mely hát ha munka is, annak örömódája inkább (3. old.).

A „munka”, ez esetben huszonegy esszé, valahol a képzet, képzelet és valóság köztes terében, mondhatnánk Univerzumában tett séta. Érzékeny, rákérdező, felfedező és felelős barangolás olyan tájakon, melyeken részben senki sem járt, de szinte minden érdemleges művész mégis, $s$ melyek itt élnek velünk, köröttünk, az időben és térben, a rejtelmekben és méltó névtelenségben. Nevet a szerző ad, olykor az alkotó, máskor inkább a megismerő, a saját világot is ekképpen tárgyiasító. „Amikor esszét írok, örülök, hogy nincs múlt, se jelen, eloszlanak a homályok, eltávolodnak a szorongások, a feszültségek, tehetetlenségeim. Tulajdonképp én sem vagyok, csak a lényem intellektuális része: a tudásom, a műveltségem, a kérdéseim és válaszaim - mindaz, ami a legjobb bennem. $S$ tán valamennyi maradandó is belőle" (uo.). A maradandósághoz pedig olyan tudás- és érzületi szférák szolgálnak megértést igénylően, mint a tematikusan válogatott írások öt fejezete, az „Istenek és emberek”, a „Menny és pokol”, a „Test és lélek”, a „Föld és ég”, a „Képzelet és valóság" építménye. Ez a kontrasztba, ellenpozícióba állítás rendszerint példák során át látható, máskor a legkifejezőbb duáliák rangjára emelt személyes rangadás jele. Olyan személyességbe illesztés, melynek a bevezetőben jelzett alkotói csönd, megértő méltóság, belátó kalandozás nem véletlenszerű tartozéka, hanem lényegi eleme. Ekként pedig nem másra hívja föl a figyelmet, mint arra, miképpen nem ismerjük, mennyire látható s mégis értelmetlenül tárgyiasult egy-egy festmény, melynek létezéséről vagy fogalmunk sem volt, vagy megértésünk és mủveltségi alázatunk hiányzott hozzá, hogy értelmezési terét érzékelni próbáljuk. Miró kapcsán írja, de szélesebb értelemben is figyelempróbáló igényt fogalmaz meg vele: „a szimbólumalkotás az emberi lét, az emberi kultúra, gondolkodás jellemzője” (167. old.). S ha csupán a térről lenne szó... De itt az istenektől a poklon át a lélekig és a képzeletig valójában minden egyesülhet, föltolulhat, megtestesedhet akár egyetlen müben is (föképp ha az éppen 
a teremtés aktusával függ össze): „Miró újrateremtette a világot. A természeti, biológiai, geometrikus formákat, tárgyakat, élőket és életteleneket, ismerős és ismeretlen lényeket. A mozgásokkal teli textúrán, képfelületen tekergő, szuggesztív, kanyargó, csavarodó mozdulatai, könnyedén felvitt ecset- és ceruzavonalai elevenen őrzik a teremtés aktusának dinamikáját. A létezés, a mikro- és makrokozmosz, a teljesség. A csakis a műalkotásokban megteremthető teljesség" (168. old.).

Ezek a futamok, melyekből S. Nagy bőségesen improvizált a Mütermek kötetben, (s tegyük hozzá: a nyomtatott Mütermek képek nélküli szöveganyag, de az elektronikusan elérhető már telített az elképesztő igényességű reprodukciókkal!), a Képekröloldalain pazarnál pazarabb időutazásokba, teremtett világokba, személyességekbe és alkotás-struktúrákba kalauzol. Nemcsak „olvashatóvá” teszi a képeket, szerzőket, egész életműveket is olykor, de a tudományos esszé speciális müfajával ajándékoz meg, melyben a hivatkozások, a fontos szakirodalom, a még lehetséges további tudás is része az elemző értelmezésnek. Nem egy utalással él S. Nagy, amikor egyetemi óráira, diákjaival közös élményképletre, jeles értelmezők soraira-műveire utalva voltaképpen nem csupán „leírja”, hanem egyszersmind megjeleníti is a belátások univerzumát. Az „én így láttam”, „ezt láttam benne” személyessége mellé odaemeli a további felfogásmódok, klasszifikációk, felmutatások és megnevezések lehetőségeit. Köztük a részvalóságokét, a kreált-szimbolizált-strukturált valóságokét, az értelmező képzelet valóságosan valótlan teremtményeit is megalkotja. Kicsiny „hízelgö" gesztussal olykor azt is mondhatnám: miként az alkotó a művét, $S$. Nagy a müértést teremti meg. $S$ a hitelesség okán nem „A jelentést”, hanem a minden jelentések számunkra-valóságának esélyét. Roppant szép példa, hogy a fennebb is utalt Labirintussal összefüggésben, s még el sem hagyva Rogier van der Weyden késő gótikán túllépő, „kora reneszánszon, Németalföldön, itáliai hatásokon, a keresztény tantételeken is" átívelő ismertetését, máris megidézi Ország Lili utolsó periódusában festett 48 képből álló Labirintus-sorozatát, melyben a Románkori Krisztust a személyesség ölelésével teszi közössé: „A Giotto padovai freskóján látható Jézus (Judás csókja, 1304-1306) mellett a chartres-i Krisztus számomra a legszebb, legvonzóbb Isten-fia arc: egy megértö, harmonikus, jó, segítö, karizmatikus ember arca. A késő román kori és a kora gótikus istenszemlélet megtestesítője. Hasonló látható Arles-ban a nyugati kapun, Saint-Denis-ben a bencés apátságban és a Notre-Dame székesegyházon. Ország Lilié leginkább a chartres-ival rokon, még pontosabban a chartres-iból és az arles-iból alakította a sajátját". Ez az „átvezetö” megidézés nemcsak arra alkalmas, hogy a meghatározó impressziót megossza velünk, de a megjelenítés képi és történeti méltóságába terjeng át. „A barna különböző árnyalataival festett, kváderkövekből álló falon (a jeruzsálemi Siratófal? megmaradt középkori templomrom? archaikus korabeli várfal?) lenyomatokat látunk. A fal elzár, körülzár, megvéd, határol, távol tart. Falakkal vették körül a középkori városokat. Falakat emelünk magunk és mások közé - átvitt értelemben. A Románkori Krisztusban a fal szakrális jelekkel, utalásokkal teli. Talán egy templom maradványa.

Héber, latin, ószláv betűtöredékek: elpusztult kultúrák emlékei. Jobbra fent az oldal szélén továbbfolytatható áramkör utal a XX. századi civilizációra. /.../ Középen a jobb karját felemelő Krisztus ujjával az ég felé mutat, mosolyog, arca derűs; ő már nem a bizánci fenyegető, trónjával mennyei hatalmat képviselő, ítélkező Isten, hanem $A$ hegyi beszéd szelíd, szeretetet, toleranciát, elfogadást hirdető mestere, aki megbékélést kínál az embereknek. A XII-XIII. században egyre több hasonló Krisztusábrázolás születik, Ország Lili is onnan idéz" (36. old.).

A könyv lapoztán persze nemcsak nagy nevek és még nagyobb művek sorjáznak előttünk (Jan Vermeer van Delft, Rogier van der Weyden, Ország Lili, Hieronymus Bosch, Jan van Eyck, Domenico Ghirlandaio, Rembrandt, Otto Dix, Chagall, Id. Pieter Bruegel, Caspar David Friedrich, Claude Monet, Farkas István, Max Ernst, Paul Klee, Joan Miró), de a látható lehetőség is a korok, alkotók, habitusok, üzenetek, képzetek, mítoszok, jelképtárak, értelmezések és befogadások sokaságára, továbbá mindezek egyénítésének merészsége is meggyőzővé válik. A műtörténész vállalása, mely társulni törekszik az elmondható világok szavakba foglalásának kalandját és valaminő esélyét még fenntartani képes saját világainkhoz, s a megértés reményét képviselő szakember alázata a teremtett világok teremtőinek műve elött. Sugárzó könyv ez. Követi az Emlékkavicsok méltóságát, átfogja a Müvészettörténet-ek belátó rangját, s közös jelentéstérbe emeli a mindenkori látnivalók lehetséges örökségét... 